\title{
Comparison of urinary oestrogen excretion in South American primates
}

\author{
J. K. Hodges*, B. A. Gulick, N. M. Czekala and B. L. Lasley \\ San Diego Zoo Research Department, P.O. Box 551, San Diego, California 92112, U.S.A.
}

\begin{abstract}
Summary. Changes in the excretion of immunoreactive oestrogens and biologically active LH were assessed from measurements on small samples of urine collected from a capuchin, a tamarin, a spider monkey and a squirrel monkey. The hormone profiles were used to time matings of the capuchin and spider monkey; conception and pregnancy ensued. Detailed analysis of one urine sample from each female by using partition chromatography and reverse-phase high-pressure liquid chromatography showed that oestrone was more abundant than oestradiol-17 $\beta$ and oestriol combined, but the relative contribution of individual oestrogens to the total oestrogen complement differed. In the sample from the capuchin, an immunoreactive oestrogen slightly less polar than oestradiol appeared to be the most abundant urinary oestrogen.
\end{abstract}

\section{Introduction}

Despite the recent increased interest in the use of South American primates for biomedical research, relatively little is known about their reproductive physiology. To date, hormonal data on female reproductive cycles are limited to the cotton-topped tamarin (Preslock, Hampton \& Hampton, 1973), the common marmoset (Hearn \& Lunn, 1975; Hearn, Abbott, Chambers, Hodges \& Lunn, 1978), the squirrel monkey (Wolf, O'Connor \& Robinson, 1977) and the owl monkey (Bonney, Dixson \& Fleming, 1979) and there have been no previous comparative studies on the reproductive endocrinology of platyrrhine monkeys,

The present paper describes the excretion of total immunoreactive oestrogen and biologically active luteinizing hormone (LH) in small volumes of urine collected from females of 4 species of South American monkey, and compares the relative amounts of individual oestrogen metabolites excreted.

\section{Materials and Methods}

\section{Urine collection}

The adult females used were a white-fronted capuchin (Cebus albifrons), a white-lipped tamarin (Saguinus fuscicollis), a common squirrel monkey (Saimiri sciureus) and a Colombian black spider monkey (Ateles fusciceps robustus). The capuchin, tamarin and spider monkey were kept outside under natural conditions at the San Diego Zoo Research Hospital. The squirrel monkey was housed indoors at the Yerkes Primate Center under dim natural lighting conditions

\footnotetext{
* Present address: Wellcome Laboratories of Comparative Physiology, The Zoological Society of London, Regent's Park, London NW1 4RY, U.K.
} 
with additional artificial illumination between 08:00 and 17:00 h. All animals were housed individually in metal cages fitted with removable sloping trays for urine collection. The tamarin was trained to enter a small verandah cage (approximately $51 \times 38 \times 30 \mathrm{~cm}$ ) attached to the side of the main cage to facilitate the collection of small volumes of urine (usually about 1-2 ml). Urine samples collected each morning over variable periods of time, usually lasting between 1 and $2 \mathrm{~h}$, were separated into two aliquots and stored at $-20^{\circ} \mathrm{C}$ until assayed. Animals were fed once daily after the completion of the urine collection and were deprived of water during the collection period.

\section{Hormone assays}

Oestrogens. The oestrogen assays, performed as described by Hodges et al. (1979), utilized a non-specific oestriol trisuccinyl-directed antiserum (S310 No. 5, G. E. Abraham) which exhibits similar antigenic cross-reactivity with oestrone, oestradiol-17ß and oestriol (Tulchinsky \& Abraham, 1971; Text-fig. 1) and also cross-reacts substantially with various other oestrogenic compounds (Table 1). Oestrogen determinations used to produce the cycle profiles shown in this study were made without a chromatographic step and the parallelism of displacement in Text-fig. 1 forms the basis of use of the S310 antibody to measure total immunoreactive oestrogen. Total binding capacity of the antibody was $61 \%$ for $\left[{ }^{3} \mathrm{H}\right]$ oestrone, $72 \%$ for $\left[{ }^{3} \mathrm{H}\right]$ oestradiol- $17 \beta$ and $54 \%$ for $\left[{ }^{3} \mathrm{H}\right]$ oestriol. Urine samples were diluted with phosphate buffer $(\mathrm{pH} 5 \cdot 0)$ and hydrolysed by incubating with $0.02 \mathrm{ml} \beta$-glucuronidase-arylsulphatase (Boehringer, Mannheim, West Germany) at $37^{\circ} \mathrm{C}$ for $24 \mathrm{~h}$. Procedural losses were monitored for all samples by the addition of tracer amounts of $\left[{ }^{3} \mathrm{H}\right.$ loestrone (sp. act. $91 \mathrm{Ci} / \mathrm{mmol}$ ) before extraction with ether. All labelled hormones were repurified on celite microcolumns before use. The mean \pm s.d. recovery value over 7 total oestrogen assays was $83 \pm 6 \%$. Assay sensitivity was $10 \mathrm{pg} /$ tube and buffer blanks extracted with each assay were less than this value. Due to large dilutions required in the assay, interassay precision (expressed as the coefficient of variation) based on the measurement of replicate samples from two separate pools of urine was 17 and $22 \%$.

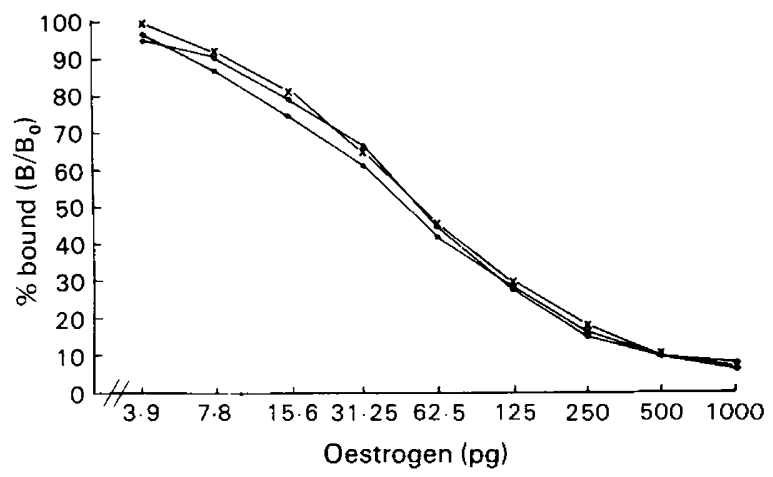

Text-fig. 1. Displacement of $\left[{ }^{3} \mathrm{H}\right]$ oestriol from the $\mathrm{S} 310$ (oestriol) antibody by increasing doses of oestrone $(\Theta)$, oestradiol-17 $\beta(O)$ and oestriol $(x)$, expressed as percentage of total bound.

Continuous-elution celite-column partition chromatography and reverse-phase high-pressure liquid chromatography (HPLC) were performed on one urine specimen from each of the 4 females to determine the relative contribution of component oestrogens to the total oestrogen value. The same antibody (S310 No. 5) was used for all determinations. After hydrolysis of 0.5 $\mathrm{ml}$ urine, the hydrolysates were separated into four $0.1 \mathrm{ml}$ aliquots. One aliquot was used for measurement of total immunoreactive oestrogen as previously described (Hodges, Czekala \& 
Lasley, 1979). Co-chromatography on HPLC was performed on a second aliquot after the addition of 2000 c.p.m. each of $\left[{ }^{3} \mathrm{H}\right]$ oestrone, $\left[{ }^{3} \mathrm{H}\right.$ loestradiol- $17 \beta$ (sp. act. $101 \mathrm{Ci} / \mathrm{mmol}$ ) and $\left[{ }^{3} \mathrm{H}\right.$ ]oestriol (sp. act. $70 \mathrm{Ci} / \mathrm{mmol}$ ) and subsequent ether extraction. Two other aliquots were stored. After drying with nitrogen, each of the extractants was resuspended in $0.05 \mathrm{ml}$ acetonitrile (Mallinckrodt, St Louis, Missouri) and $0.02 \mathrm{ml}$ was then injected onto a $4.6 \times 250$ mm Licrosorb C-18 column (Altex) using acetonitrile:water $(40: 60 \mathrm{v} / \mathrm{v})$ as a solvent system. Fractions were collected at 0.3 -min intervals for $12 \mathrm{~min}$, blown dry with nitrogen, reconstituted in $1.0 \mathrm{ml}$ phosphate buffer and then monitored for radioactivity and immunoreactivity. Mean \pm s.d. recovery of labelled oestrone, oestradiol and oestriol after extraction and HPLC was $51 \cdot 0 \pm 2 \cdot 2,63 \cdot 0 \pm 6 \cdot 1$ and $59 \pm 5 \cdot 3 \%$ respectively ( 4 experiments).

Table 1. Cross-reactivities of the $S 310$ antibody and two other 'non-specific' antibodies with various oestrogenic compounds

\begin{tabular}{|c|c|c|c|}
\hline \multirow[b]{2}{*}{ Oestrogen } & \multicolumn{3}{|c|}{$\% \mathrm{~B} / \mathrm{B}_{0}$ with $100 \mathrm{pg}$} \\
\hline & $\begin{array}{c}E_{3} \text { Abraham } \\
\text { (S310) }\end{array}$ & $\mathrm{E}_{2}$ Hendrickx & $\mathrm{E}_{2} \mathrm{NIH}$ \\
\hline Oestrone & 34 & 40 & 39 \\
\hline Oestradiol-17 $\beta$ & 26 & 25 & 23 \\
\hline Oestriol & 33 & 87 & 78 \\
\hline 16-Epioestriol & 27 & 51 & 70 \\
\hline 16-Keto- $17 \beta$-oestradiol & 30 & 65 & 68 \\
\hline $16 \alpha$-Hydroxyoestrone & 43 & 79 & 75 \\
\hline 17-Epioestriol & 45 & 78 & 82 \\
\hline 16,17-Epioestriol & 66 & 86 & 91 \\
\hline 2-Methoxyoestriol & 101 & 100 & 92 \\
\hline 2-Hydroxyoestrone & 95 & 98 & 91 \\
\hline Equilin & 56 & 66 & 74 \\
\hline D-Equilenin & 67 & 62 & 84 \\
\hline
\end{tabular}

Values (mean of 3 determinations) represent percentage $B / B_{0}$, where $B_{0}$ is radioactivity bound in the absence of unlabelled hormone and $B$ is radioactivity bound in the presence of $100 \mathrm{pg}$ unlabelled hormone. Each antibody was used at the recommended working dilution $\left(\mathrm{E}_{3}\right.$ Abraham 1:6000; $\mathrm{E}_{2}$ Hendrickx $1: 40000 ; \mathrm{E}_{2}$ NIH $\left.1: 80000\right)$.

Co-chromatography using celite columns was performed on the two remaining aliquots according to the method of Anderson, Hopper, Lasley \& Yen (1976) by monitoring radioactive and immunoreactive oestrone, oestradiol- $17 \beta$ and oestriol across the appropriate elution profiles at $0.5 \mathrm{ml}$ intervals. Tritiated pure steroid (2000 c.p.m. of oestrone and oestradiol-17 $\beta$ or 2000 c.p.m. of oestriol) was added to each aliquot to monitor the radioactivity eluted in each fraction. Oestrone and oestradiol-17 $\beta$ were eluted from an ethylene glycol :celite $(1: 2 \mathrm{v} / \mathrm{w})$ column with $3.5 \mathrm{ml}$ of 15 and $40 \%$ ethyl acetate in iso-octane, respectively (Abraham, Tulchinsky \& Korenman, 1970); oestriol was eluted from a water:celite $(1: 3 \mathrm{v} / \mathrm{w})$ column with $5 \mathrm{ml}$ of 100\% ethyl acetate (Tulchinsky \& Abraham, 1971).

The oestrone, oestradiol-17 $\beta$ and oestriol fractions eluted from the celite columns were assayed using the $\mathrm{S} 310$ antibody and oestrone, oestradiol-17 $\beta$ and oestriol respectively as tracer and standards.

$L H$. LH values were measured with the in-vitro testosterone response of rat Leydig cells originally described by Dufau, Mendelson \& Catt (1974) and Dufau, Pock, Neubauer \& Catt (1976) and modified by Hodges et al. (1979). The first international reference preparation of human urinary gonadotrophin (WHO 70/45) was used as the LH standard over the range 31-1000 ng/tube. For the assay of urine samples, $0.1 \mathrm{ml}$ unprocessed urine was introduced directly into the assay incubation vials. Testosterone production in the incubation vials was 
determined by a standard radioimmunoassay procedure (Anderson et al., 1976) using a testosterone antibody (Abraham S-7H-No. 7) which exhibits maximum cross-reaction with $5 \alpha$-dihydrotestosterone (17\%). The working sensitivity of the $\mathrm{LH}$ assay was approximately $40 \mathrm{ng}$ $\mathrm{LH} /$ tube and the interassay precision (expressed as the coefficient of variation), based on the measurement of replicate samples of diluted monkey pituitary homogenate, was $16.5 \%$.

Urinary creatinine content was estimated in all samples according to the method of Taussky (1954) and the value divided into the urinary hormone measurements to help compensate for collection errors resulting from variable fluid intake and output and from variable periods of collection. The values of total immunoreactive oestrogen and bioactive $\mathrm{LH}$ in urine were therefore expressed as concentration per $\mathrm{mg}$ creatinine.

\section{Results}

The relative amounts of the 3 oestrogens in the urine samples from the 4 females of different species are shown in Text-fig. 2. In the tamarin, squirrel monkey and spider monkey, the major immunoreactive oestrogen corresponded to the elution pattern of $\left[{ }^{3} \mathrm{H}\right]$ oestrone. Although oestrone was also identified as an abundant oestrogen metabolite in capuchin urine, similar amounts of another immunoreactive substance were measured in the fractions immediately after the peak of $\left[{ }^{3} \mathrm{H}\right]$ oestriol. Relative to oestrone, a much smaller amount of immunoreactivity was also eluted from the column immediately after the $\left[{ }^{3} \mathrm{H}\right]$ oestriol peak in the squirrel monkey.

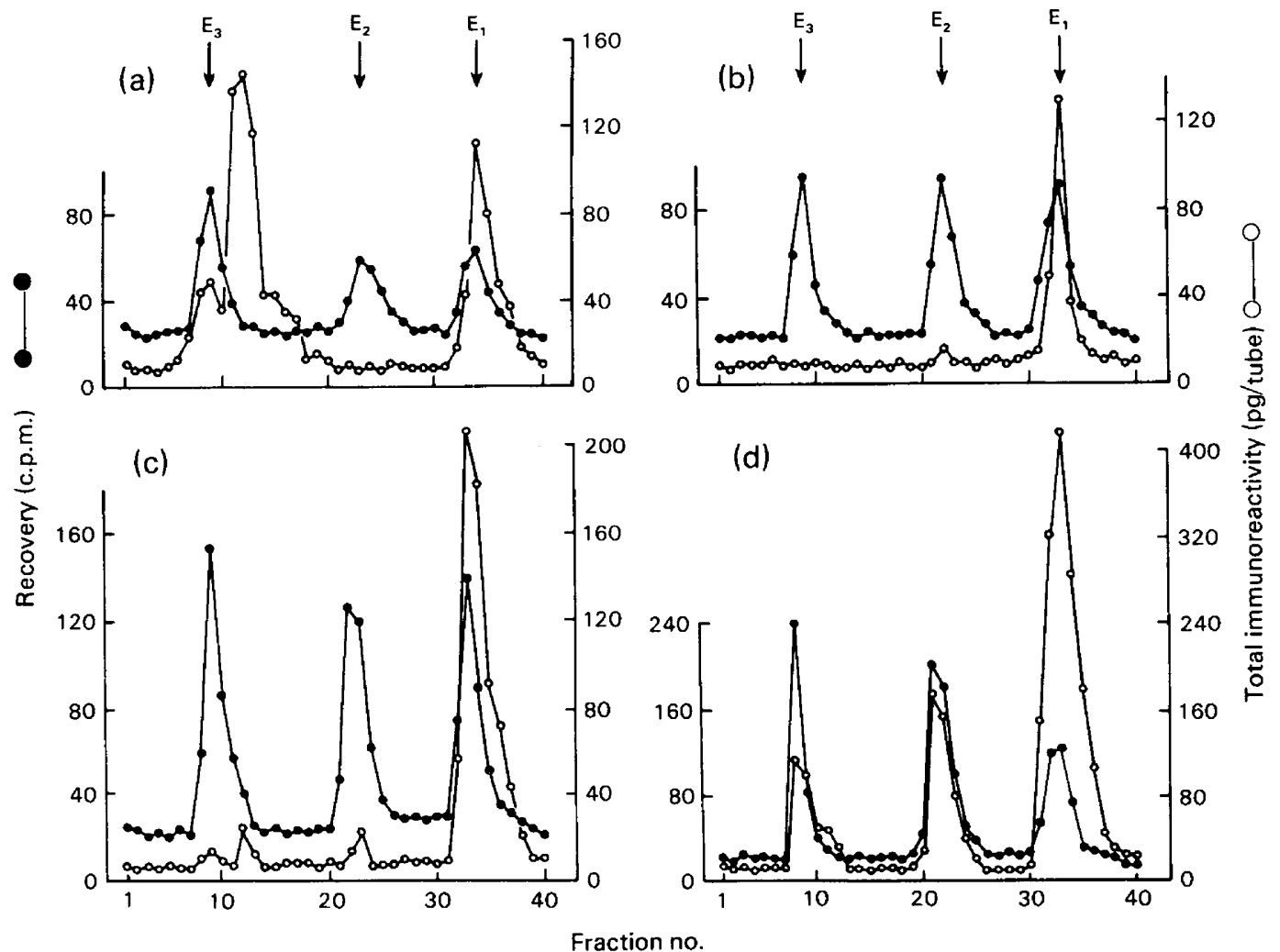

Text-fig. 2. Total oestrogen immunoreactivity $(O)$ compared with the recovery of $\left[{ }^{3} \mathrm{H}\right]$ oestrone $\left.\left(\mathrm{E}_{1}\right),{ }^{3} \mathrm{H}\right]$ oestradiol-17 $\beta\left(\mathrm{E}_{2}\right)$ and $\left[{ }^{3} \mathrm{H}\right]$ oestriol $\left(\mathrm{E}_{3}\right)(\bullet)$ after reverse-phase high-pressure liquid co-chromatography of hydrolysed urine of a non-pregnant (a) capuchin, (b) tamarin, (c) squirrel monkey, and (d) spider monkey. 
Quantitative values were obtained by celite column co-chromatography. Single immunoreactive peaks parallel to the elution profiles of the respective pure tritiated steroid were obtained for each hormone, indicating the absence of any overlap from potential cross-reacting steroids (see Anderson et al., 1976). Moreover, the single peak in the oestriol fraction indicated that the undefined oestrogen eluted from the HPLC column (close to oestriol) was excluded by celite separation and did not interfere with the individual measurement of oestriol. Considering the non-specificity of the S310 antibody these chromatography profiles demonstrated that the celite system used was an efficient method of separating urinary steroids in the species studied. As shown in Table 2, oestrone predominated over oestradiol-17 $\beta$ and oestriol combined in all 4 species. In the tamarin and spider monkey virtually all of the oestrogenic immunoreactivity was accounted for by oestrone, oestradiol-17 $\beta$ and oestriol, but in the capuchin and squirrel monkey there was a marked discrepancy between the sum of the 3 oestrogens and the total immunoreactivity, indicating that approximately 40 and $21 \%$ respectively of the total value was derived from oestrogens other than oestrone, oestradiol-17 $\beta$ and oestriol.

Table 2. Relative concentrations $(\mu \mathrm{g} / \mathrm{ml})$ of oestrogens, in monkey urine, measured after separation with celite column partition chromatography and the total oestrogen immunoreactivity

\begin{tabular}{lcccccc}
\hline Monkey & $\begin{array}{c}\text { Oestrone } \\
\left(\mathrm{E}_{1}\right)\end{array}$ & $\begin{array}{c}\text { Oestradiol-17 } \\
\left(\mathrm{E}_{2}\right)\end{array}$ & $\begin{array}{c}\text { Oestriol } \\
\left(\mathrm{E}_{3}\right)\end{array}$ & $\mathrm{E}_{\mathbf{1}}+\mathrm{E}_{2}+\mathrm{E}_{\mathbf{3}}$ & $\begin{array}{c}\text { Total } \\
\text { oestrogens }\end{array}$ & \% difference \\
\hline Capuchin & 0.210 & 0.019 & 0.065 & 0.294 & 0.486 & 39.5 \\
Tamarin & 3.240 & 0.095 & 0.030 & 3.365 & 3.540 & 4.8 \\
Squirrel & 0.392 & 0.024 & 0.008 & 0.424 & 0.536 & 20.9 \\
Spider & 0.408 & 0.113 & 0.079 & 0.600 & 0.645 & 6.9 \\
\hline
\end{tabular}

Values are the mean of 3 determinations.

\section{Urinary hormone profiles}

The total immunoreactive oestrogen profile in a white-fronted capuchin (Text-fig. 3a) showed 3 abrupt preovulatory oestrogen increments with smaller and more prolonged elevations above baseline during the (assumed) luteal phase. LH surges were detected either the same day or the day after maximum oestrogen levels. The intervals between successive periods of menstruation and oestrogen or LH peaks suggested a cycle length of 18-19 days. Conception resulted from a single timed mating on 26 August. In the white-lipped tamarin there were 2 peaks in oestrogen concentrations 18 days apart, each followed 1 day later by an LH surge (Text-fig. 3b). The preovulatory increment in urinary oestrogen levels was more prolonged in the spider monkey (Text-fig. 3c) than in the tamarin or capuchin. LH surges were prominent on 9 May and 29 May, and less so on 21 June. The hormone profiles suggested a cycle length of 20-22 days in this individual. Pregnancy ensued from selected matings during the last cycle shown. Although small increments in total oestrogen and LH levels were seen in the squirrel monkey (Text-fig. 3d) there was no obvious cyclicity in the pattern of hormone excretion. The very low urinary oestrogen con centrations/mg creatine also suggest that the cycle was not associated with normal ovulation.

\section{Discussion}

This paper extends the use of a recent methodological approach (Hodges et al., 1979) to the measurement of immunoreactive oestrogen and biologically active LH to urine samples from females of 4 South American primate species. Valid inter-specific comparison of urinary oestrogen levels measured by radioimmunoassay is often complicated by the considerable variation in chemical nature and relative abundance of the different oestrogen metabolites present. In this study a non-specific oestrogen antibody was used in combination with the high 


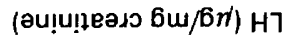
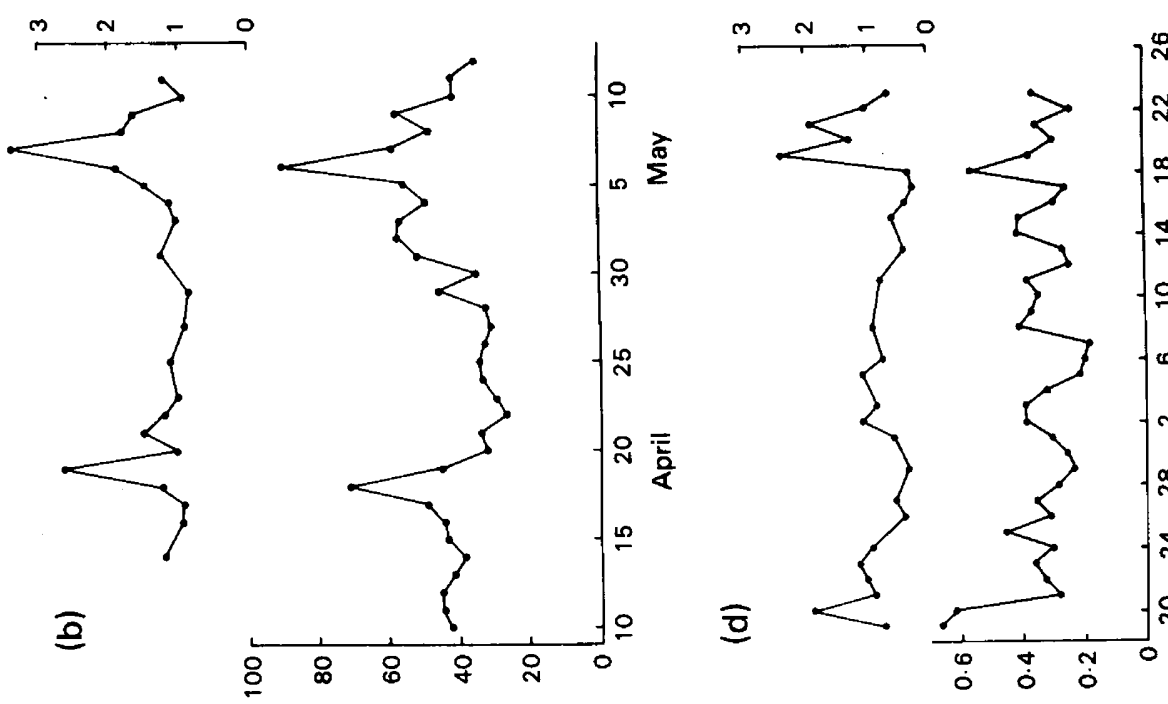

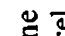

늘 ง 苛 $\infty$ 产. 톨 동 菎它 过 退旁 巳

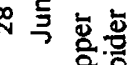
글 के 농
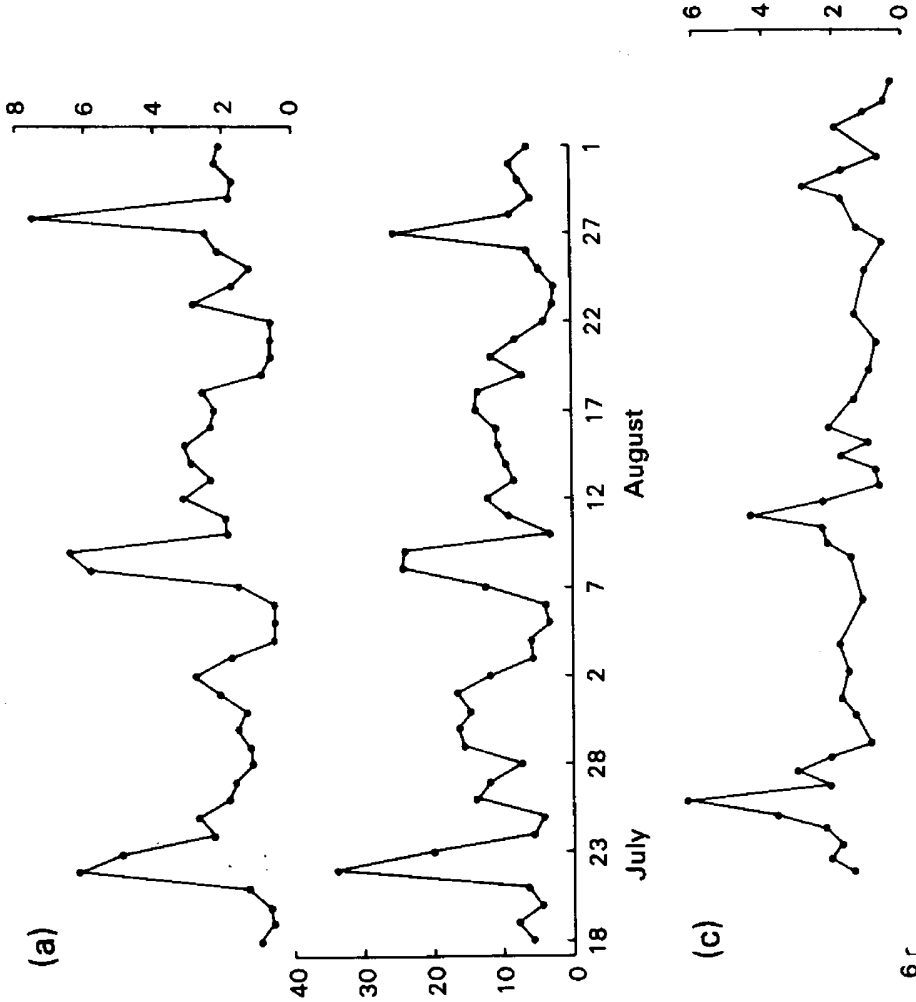

.

車 年

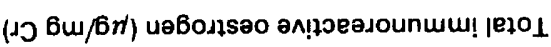


resolution afforded by HPLC in an attempt to overcome this problem. When used alone, the S310 antibody provides a reliable estimation of total oestrogen immunoreactivity; when used with continuous elution HPLC and/or partition chromatography, component oestrogens can be separated for individual measurement. Thus, the specificity of the measurement becomes relatively independent of the properties of the antibody but instead relies principally on the resolving powers of the separation procedure. The usefulness and high resolution provided by the simple two-step process of celite-column partition chromatography in conjunction with reverse-phase HPLC has also been demonstrated for the measurement of testicular steroids (Cochran \& Ewing, 1979).

The present data indicate the predominance of oestrone over oestradiol-17 $\beta$ and oestradiol in single urine samples from each of the species studied. Measurement of a larger number of samples is, however, required to establish whether this pattern of excretion is typical of all members of the species. Shackleton (1974) and Lunn (1978) studied mid- to late-pregnant common marmosets (Callithrix jacchus) and reported that oestradiol-17 $\beta$ was excreted in the greatest amounts. Changes in oestrogen metabolism can be expected during pregnancy and this may account for the difference from the present results. However, the present findings are inconsistent with Shackleton's (1974) proposal that in New World monkeys oestradiol-17 $\beta$ is largely excreted unmetabolized.

Although slight differences between total oestrogen and the sum of oestrone, oestradiol-17 $\beta$ and oestriol values are to be expected because of additional interactions with undefined oestrogens (Adessi, Goutte-Coussieu, Nhuan \& Jayle, 1976; Czekala, Hodges \& Lasley, 1980), the large discrepancy between these values in the capuchin and squirrel monkey is of interest. The HPLC data (Text-fig. 2) suggest that an immunoreactive oestrogen slightly less polar than oestriol (and excluded from the individual measurements by the celite chromatography) is largely responsible for the discrepancy. Although this oestrogen has not yet been identified, it appears to be the most abundant oestrogen metabolite in capuchin urine and has also been detected in large amounts during pregnancy in the Douc langur and black lemur (Czekala et al., 1980). Isolated fractions containing the 'unidentified' oestrogen from capuchin urine are active in the rat uterine cytosol receptor assay (unpublished data).

The normality of the total oestrogen and $\mathrm{LH}$ measurements for the capuchin and spider monkey was shown by the success of matings (resulting in conception) timed in relation to the hormone profiles. Data on the capuchin cycle have been published (Hodges et al., 1979) but hormone profiles in the spider monkey and white-lipped tamarin have not been previously reported. The cycle lengths for the 2 females studied are similar to values from other studies of New World monkeys (see Preslock et al., 1973; Hearn et al., 1978; Bonney et al., 1979). The present findings also suggest a species difference in the pattern of oestrogen excretion, the gradual and prolonged preovulatory-like oestrogen increment in the spider monkey contrasting markedly with the more abrupt rise in the capuchin and tamarin. However, studies on more females are required to substantiate this finding.

Although these data provide useful qualitative profiles of oestrogen and LH excretion, it is difficult to make comparisons between individual animals. The study does, however, provide a basis for further comparative investigation of oestrogen excretion in South American primates. The observation in the capuchin that the most abundant urinary oestrogen metabolite does not appear to be oestrone, oestradiol- $17 \beta$ or oestriol indicates the need for caution when assessing oestrogen excretion solely in terms of the three 'classical' oestrogens.

We are grateful to Dr K. Gould and Mr R. Schwartz for collection of urine samples. The World Health Organization supplied the human urinary LH standard. The work was supported jointly by the National Science Foundation grant No. PCM 78-16833 and the National Institutes of Health grant No. 1-508-RR-09002-03. J.K.H. was in receipt of a Postdoctoral Fellowship from the Future H. McDonald Foundation. 


\section{References}

Abraham, G.E., Tulchinsky, D. \& Korenman, S.G. (1970) Chromatographic purification of estradiol$17 \beta$ for use in radioligand assay. Biochem. Med. 3, 365-368.

Adessi, G.L., Goutte-Coussieu, C., Nhuan, Q.W. \& Jayle, H.F. (1976) Variations of the excretion curves of seven urinary estrogens during late pregnancy. Eur. J. Obstet. Gynec. Reprod. Biol. 6, 319-324.

Anderson, D.C., Hopper, B.R., Lasley, B.L. \& Yen, S.S.C. (1976) A simple method for the assay of eight steroids in small volumes of plasma. Steroids $\mathbf{2 8}$, 179-196.

Bonney, R.C., Dixson, A.F. \& Fleming, D. (1979) Cyclic changes in the circulating and urinary levels of ovarian steroids in the adult female owl monkey (Aotus trivirgatus). J. Reprod. Fert. 56, 271-280.

Cochran, R.C. \& Ewing, L.L. (1979) Celite column chromatography followed by reverse phase high pressure liquid chromatography; a simple, two-step method for separating 14 testicular steroids. $J$. Chromatog. 173, 175-181.

Czekala, N.M., Hodges, J.K. \& Lasley, B.L. (1980) Pregnancy monitoring in diverse primate species by estrogen and bioactive luteinising hormone determinations in small volumes of urine. J. med. Primat. (in press).

Dufau, M.L., Mendelson, C.R. \& Catt, K.J. (1974) A highly sensitive in vitro bioassay for luteinizing hormone and chorionic gonadotropin: Testosterone production by dispersed Leydig cells, $J$, clin. Endocr. Metab. 39, 610-613.

Dufau, M.L., Pock, R., Neubauer, A. \& Catt, K.J. (1976) In vitro bioassay of LH in human serum: the rat interstitial cell testosterone (RICT) assay. J. clin. Endocr. Metab. 42, 958-969.
Hearn, J.P. \& Lunn, S.F. (1975) The reproductive biology of the marmoset monkey (Callithrix jacchus). In The Breeding of Simians and their uses in Developmental Biology (Lab. Anim. Handbook No. 6), pp. 191-202. Eds F. T. Perkins \& P. N. O'Donoghue. Laboratory Animals Ltd, London.

Hearn, J.P., Abbott, D.H., Chambers, P.L., Hodges, J.K. \& Lunn, S.F. (1978) Use of the common marmoset (Callithrix jacchus) in reproductive research. Primate Med. 10, 40-49.

Hodges, J.K., Czekala, N.M. \& Lasley, B.L. (1979) Estrogen and luteinizing hormone secretion in diverse primate species from simplified urinary analysis. $J$. med. Primatol. 8, 349-364.

Lunn, S.F. (1978) Urinary oestrogen excretion in the common marmoset (Callithrix jacchus). In Biology and Behaviour of Marmosets, pp. 67-74. Eds $\mathbf{H}$. Rothe, H. J. Walters \& J. P. Hearn. Eigenverlag Rothe, Göttingen.

Preslock, J.P., Hampton, S.H. \& Hampton, J.K., Jr (1973) Cyclic variations of serum progestins and immuno-reactive estrogens in marmosets. Endocrinology 92, 1096-1101.

Shackleton, C.H.L. (1974) Progesterone and oestrogen metabolism in the pregnant marmoset (Callithrix jacchus). J. Steroid Biochem. 5, 597-600.

Taussky, H.H. (1954) A microcolorimetric determination of creatinine in urine by the Jaffe reaction. J. biol. Chem. 208, 853-681.

Tulchinsky, D. \& Abraham, G.E. (1971) Radioimmunoassay of plasma estriol. J. clin. Endocr. Metab. 32, 775-782.

Wolf, R.C., O'Connor, R.F. \& Robinson, J.A. (1977) Cyclic changes in plasma progestins and estrogens in squirrel monkeys. Biol. Reprod. 17, 228-231.

Received 17 March 1980 